\title{
PROCJENA UČINKOVITOSTI RANOG KINEZITERAPIJSKOG TRETMANA U BOLESNIKA S MOŽDANIM UDAROM
}

\author{
Sara Andrić ${ }^{1}$, Ljerka Ostojić ${ }^{1,2}$ \\ ${ }^{1}$ Klinika za fizikalnu medicinu i rehabilitaciju, Sveučilišna klinička bolnica Mostar \\ ${ }^{2}$ Fakultet zdravstvenih studija Sveučilišta u Mostaru, Bosna i Hercegovina \\ Rad je primljen 6.4.2017. Rad je recenziran 18.4.2017. Rad je prihvaćen 25.4.2017.
}

\section{SAŽETAK}

UVOD: Moždani udar (MU) stanje je akutnog poremećaja moždane cirkulacije s prolaznom ili trajnom moždanom disfunkcijom.

CILJ: Procijeniti učinkovitost ranog kineziterapijskog tretmana u ublažavanju funkcionalnih i psiholoških posljedica MU u ranoj fazi rehabilitacijskog postupka.

ISPITANICI I METODE: Studija je provedena u Klinici za fizikalnu medicinu i rehabilitaciju Sveučilišne kliničke bolnice Mostar u razdoblju od 1. studenog 2016. do 31. siječnja 2017. godine. Istraživanje je obuhvatilo 50 bolesnika s preboljelim MU koji su uključeni u kineziterapijski tretman. Za procjenu funkcionalnog statusa ispitanika koristio se Barthelov indeks. REZULTATI: U $72 \%$ slučajeva radilo se o muškarcima ( $(\mathrm{p}=0,001)$. Prosječna životna dob ispitanika bila je $72,7 \pm 7,3$ godina. U dobi od 70 i više godina bilo je $48 \%$ ispitanika $(\mathrm{p}<0,05)$. Ukupan prosječni skor bodova postignutih u Berthelovom

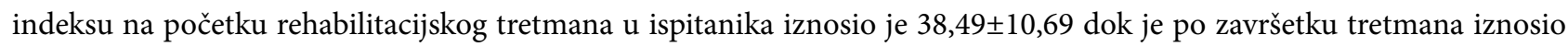
$50,65 \pm 13,27(\mathrm{p}<0,001)$. Pokazala se statistički značajno manja učestalost depresije u ispitanika na kraju rehabilitacijskog programa $(\mathrm{p}=0,003)$ kao i statistički značajna korelacija između funkcionalnog oporavka u odnosu na razinu depresije $(\mathrm{p}<0,05)$ i životne dobi $(\mathrm{p}<0,05)$.

ZAKLJUČAK: Rani kineziterapijski tretman dovodi do statistički značajnog funkcionalnog i psihološkog oporavka bolesnika s preboljelim MU.

Ključne riječi: učinkovitost, kineziterapija, moždani udar, rehabilitacija.

Osoba za razmjenu informacija:

Sara Andrić, magistar fizioterapije;

e-mail: saraandric666@gmail.com

\section{UVOD}

Moždani udar (MU) klinički je sindrom karakteriziran naglim razvojem žarišnog neurološkog deficita, vaskularne geneze (infarkt ili hemoragija), a simptomi koreliraju s veličinom i mjestom (mjestima) oštećenja mozga, ali i s vremenom proteklim od nastanka MU do tenutka procjene (1). Ciljevi liječenja osoba $s$ akutnim MU su smanjenje primarnog neurološkog oštećenja trombolizom ili neuroprotekcijom kao i monitoriranje i prevencija sekundarnih komplikacija, kao npr. porast intrakranijskog tlaka (2).

$\mathrm{U}$ ranoj fazi liječenja i rehabilitacije bolesnici $s$ MU često imaju hemiplegiju i mlohave mišiće, te su skloni razvoju kontraktura. U toj fazi rehabilitacije potrebno je pravilno namještanje u krevetu, pravilno namještanje i potpora ruke u sjedećem položaju (3). Svi zglobovi na plegičnim ekstremitetima trebaju biti pasivno razgibavani ako nema strukturnih promjena u punom rasponu opsega pokreta bar jednom dnevno s ciljem prevencije kontraktura (4). Potrebno je povećati ponavljanje opterećenjem tjelesne težine (gravitacijske vježbe, antigravitacijske vježbe, sjedni-ustani vježbe), progresivni trening $s$ otporom, vježbe izdržljivosti (sobni bicikl) (4). Već nakon nekoliko sati ili dana nakon MU tonus mišića 
počinje rasti progresivno i u toj se fazi oporavka primjenjuju različiti kineziterapijski postupci. Jedan od najproširenijih je Bobath koncept uz primjenu vježbi koje teže normaliziranju tonusa mišića i preveniranju jačeg spazma. To se postiže kroz specifično refleksno inhibirajuća namještanja i pokrete (5). Kabat i sur. su razvili propioceptivnu neuromišićnu facilitaciju (PNF), koja se sastoji od brzog istezanja i manualnog otpora u aktivnosti mišića ruku ili nogu u funkcionalnom smjeru koji je često spiralan i dijagonalan, koristeći sve tri dimenzije. PNF je korisnija metoda kod slabosti mišića koja nije uzrokovana oštećenjem gornjih motoneurona. Do sada nije provedeno kliničko istraživanje kojim bi se dokazalo da primjena bilo koje navedene metode daje bolje rezultate i konačni ishod od konvencionalne kineziterapije (3). Neurorazvojne tehnike imaju za cilj inhibirati spazam i sinergije, koristeći se inhibitornim držanjem (posturama) i pokretima i olakšavajući normalne automatske pokrete koji se uključuju u voljni pokret (4).

Cilj ortoze kod terapije za ruku i šaku je: održavanje opsega pokreta i funkcijskih položaja zglobova, spriječavanje vezivnih kontraktura, povećanje duljine mekih tkiva i održavanje opsega pokreta, te facilitiranje funkcije (6). Kod kineziterapije za ruku potrebno je pravilno pozicioniranje i namještanje, provođenje vježbi pasivnog raspona pokreta, kao i zadržavanje normalnog položaja ramena i humeroskapularnog ritma (4). Elektrostimulacija (ES) rutinski se ne prepisuje za stimulaciju mišića gornjeg ekstremiteta nego je indicirana u bolesnika koji imaju manuelni mišićni test (MMT) 2/5 i ES provodi educirani fizioterapeut. Cilj ES-a je povećanje snage. Jedna od metoda kojom se uspješno poboljšava funkcija hemiparetične šake je elektromiografski (EMG) trening s povratnom spregom (engl. Biofeedback) (6). Do klinički vidljivog poboljšanja brzine i snage mišićne kontrakcije dolazi ako bolesnik više koristi slabiju ruku (paretičnu) uz istovremenu funkcionalnu blokadu zdrave ruke, a što je princip poznat kao terapija ograničenjem pokreta zdrave strane (engl. Constraint-induced movement therapy, CIMT) (3).
Kod nepokretnog bolesnika na početku kineziterapije potrebno je maksimalno uspostavljati i razvijati kontrolu trupa i vježbe pripreme hodanja kao što su držanje, ravnoteža i prijenos težine na hemiparetičnu nogu. Ponavljajući trening preko određivanja krajnjeg cilja (engl. repetitive training) preporuča se bolesnicima koji imaju slabost gornjeg ili donjeg ekstremiteta s ciljem zadavanja zadataka izvođenja ponavljajućeg pokreta (7). Terapija hoda na pokretnoj traci za hodanje s ili bez tjelesne težine koristi se za povećanje izdržljivosti mišića i za povećanje brzine pokreta. Kod spazma najčešće se koristi aplikacija botulinum toksina u spastični mišić. Botulinum toksin se aplicira u spastični mišić s ciljem smanjenja spazma. Nakon aplikacije obavezno je intenzivirati kineziterapiju (8).

Njega bolesnika i radna terapija može se temeljiti na restauraciji funkcije ili na pronalaženju kompenzatornih mehanizama za onemogućenu funkciju (6). Restorativna radna terapija uključuje u terapiju pokrete koji se vrše s obje ruke (zdravom i bolesnom) $(3,7)$.

Cilj ovog istraživanja je procijeniti učinkovitost ranog kineziterapijskog tretmana u ublažavanju funkcionalnih i psiholoških posljedica MU u ranoj fazi rehabilitacijskog postupka.

\section{ISPITANICI I METODE}

Istraživanje je provedeno u Klinici za fizikalnu medicinu i rehabilitaciju Sveučilišne kliničke bolnice Mostar u razdoblju od 1. studenog 2016. do 31. siječnja 2017. godine. Istraživanje je obuhvatilo 50 bolesnika s preboljelim MU koji su uključeni u kineziterapijski tretman. Funkcionalni i psihološki status kod ispitanika se ocjenjivao pri prijemu u Kliniku za fizikalnu medicinu i rehabilitaciju i na otpustu s hospitalizacije. Za procjenu funkcionalnog statusa ispitanika koristio se Barthelov indeks (9), a za procjenu psihološkog statusa bolesnika provedeno je anketiranje pomoću Ljestvice bolničke anksioznosti i depresije (Hospital Anxiety and Depression scale HADS) (10).

Barthelov indeks je izravna mjera onih aktivnosti koje bolesnik može izvesti i na temelju njega ocjenjuje se koliko je postojeće ograničenje, odnosno 
poremećaj funkcije. Ovaj indeks obuhvata 10 kategorija: hranjenje, osobna higijena, kupanje, oblačenje, kontrola pražnjenja mokraćnog mjehura, kontrola pražnjenja debelog crijeva, kretanje od invalidskih kolica do kreveta i obrnuto, penjanje i silaženje niz stepenice, odlazak u toalet, hod po ravnom (ili ako ne može da hoda korištenje invalidskih kolica), penjanje i silaženje niz stepenice. Svako pitanje se posebno boduje u ovisnosti od toga je li bolesnik samostalan u vršenju određene radnje ili mu je potrebna pomoć druge osobe. Bodovanje je od 0 (najlošiji skor) do 105 (najbolji skor). Razine nesposobnosti prema BI skoru su: 0-24 potpuna nesposobnost; 25-49 značajna; 50-74 srednja; 75-90 blaga; 91-105 minimalna (9).

HADS je upitnik za procjenu depresije i anksioznosti. Sastoji se od 14 pitanja, sedam za anksioznost i sedam za depresiju. Odgovori su bodovani od 0 do 3. Zbroj parnih pitanja vezan je za depresiju, a zbroj neparnih za anksiozne poremećaje. Za upitnik su važne tri razine zbroja odgovora: zbroj odgovora manji od 8 ne ukazuje na depresivne ili anksiozne poremećaje; zbroj između 8 i 10 (uključivo 8 i 10) ukazuje na takozvane granične slučajeve, odnosno na ispitanike kojima treba obratiti veću pozornost; zbroj od 11 ili više upućuje na klinički depresivne ili anksiozne poremećaje i kod ovih pacijenata bila bi neophodna dalje analiza u tom pravcu (10).

Kriteriji za uključivanje pacijenata $u$ ovu studiju su: prvi MU u životu te prethodno liječenje u jedinici intenzivne njege u Klinici za neurologiju.

Faktori isključenja bili su: tumori mozga, kardiopatije, infektivne bolesti. Etiološka dijagnoza CVI postavljena je na osnovu nalaza magnetne rezonancije.

Prikupljeni podatci statistički su obrađeni pomoću metoda deskriptivne statistike. Distribucija vjerojatnosti kvantitativnih varijabli testirana je na normalnost Smirnov-Kolmogorovljevim testom. Budući da raspodjela varijabli nije odstupala od normalne za prikaz srednje raspršenja rabljeni su aritmetička sredina (M) i standardna devijacija (SD). Za utvrđivanje razlika među skupinama rabljen je t-test za nezavisne uzorke. $\mathrm{Za}$ analizu kategoričkih varijabli rabljen je $\chi 2$ test. Za utvrđivanje korelacije između varijabli rabio se Spearmanov test korelacije.
Dobivene statističke razlike prihvaćene su kao statistički značajne za $p<0,05$. Za statističku analizu dobivenih podataka rabljen jer programski sustav SPSS for Windows (inačica 13.0, SPSS Inc, Chicago, Illinois, SAD) i Microsoft Excell (inačica Office 2007, Microsoft Corporation, Redmond, WA, SAD).

\section{REZULTATI}

Od ukupnog broja ispitanika u $72 \%(n=36)$ slučajeva radilo se o muškarcima te u $38 \%(\mathrm{n}=14)$ slučajeva o ženama $\left(\chi^{2}\right.$ test $\left.=9,680 ; \mathrm{df}=1 ; \mathrm{p}=0,001\right)($ Slika 1$)$.

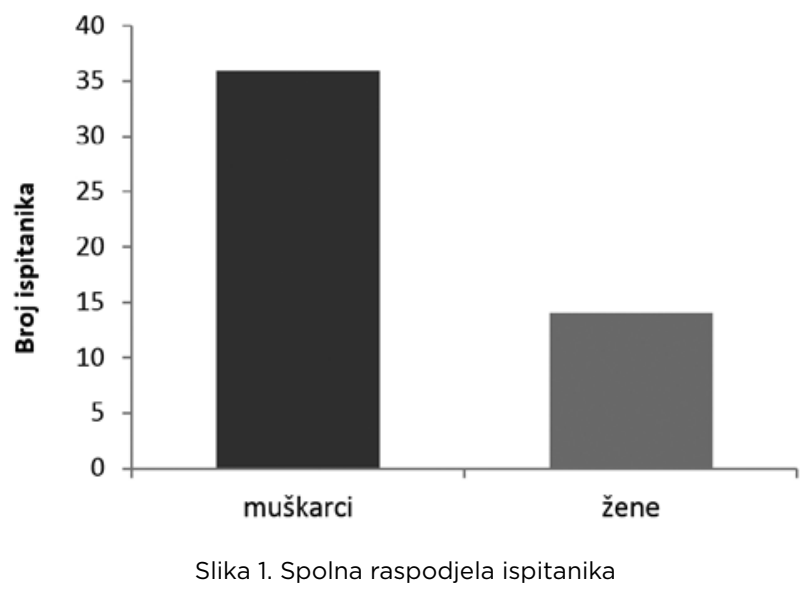

Prosječna životna dob ispitanika bila je $72,7 \pm 7,3$ godina. Najstariji ispitanik imao je 86 godina, a najmlađi 51. U životnoj dobi do 55 godina bilo je $10 \%$ $(\mathrm{n}=5)$ ispitanika, u životnoj dobi od 55 do 69 godine $42 \%(\mathrm{n}=21)$ ispitanika te $\mathrm{u}$ dobi od $70 \mathrm{i}$ više godina $48 \%(\mathrm{n}=24)$ ispitanika $\left(\chi^{2}\right.$ test $\left.=12,520 ; \mathrm{df}=2 ; \mathrm{p}<0,05\right)$ (Slika 2).

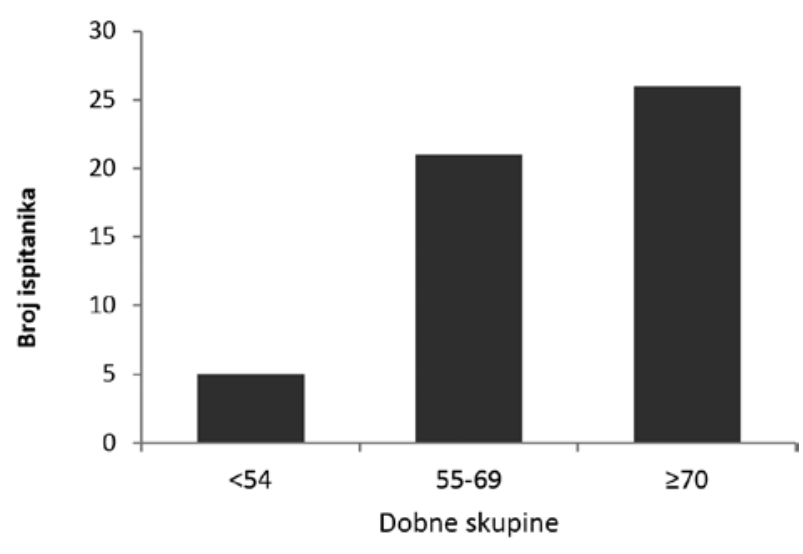

Slika 2. Dobna raspodjela ispitanika

Ukupan prosječni skor bodova postignutih u Berthelovom indeksu na početku rehabilitacijskog tretmana u ispitanika iznosio je $38,49 \pm 10,69$ 
dok je po završetku tretmana iznosio $50,65 \pm 13,27$ što se pokazalo statistički značajno $(t=5,926$, d.f. 48; $\mathrm{p}<0,001)$. Statističkom analizom odgovora $\mathrm{u}$ Berthelovom indeksu na početku i na kraju rehabilitacijskog tretmana pokazala se statistički značajna razlika u rezultatima osam domena. Naime, ispitanici statistički značajno većom ocjenom ocjenjuju mogućnost obavljanja osobne higijene $(\mathrm{p}<0,5)$, hranjenja $(\mathrm{p}<0,5)$, korištenja WC-a $(\mathrm{p}<0,5)$, oblačenja $(\mathrm{p}<0,5)$, pokretljivosti $(\mathrm{p}<0,5)$, kontrole mokrenja $(\mathrm{p}<0,5)$, transfera krevet/stolica $(\mathrm{p}<0,5)$, i kontrole stolice $(\mathrm{p}<0,5)$ (Tablica 1$)$.

Tablica 1. Usporedba ocjena svakodnevnog života pacijenata dobivenih Berthelovim indeksom na početku i na kraju rehabilitacijskog tretmana

\begin{tabular}{|c|c|c|c|c|c|c|}
\hline \multirow[t]{2}{*}{ Domena } & \multicolumn{2}{|c|}{$\begin{array}{l}\text { Na početku } \\
\text { rehabilitacijskog } \\
\text { tretmana } \\
\end{array}$} & \multicolumn{2}{|c|}{$\begin{array}{l}\text { Na kraju } \\
\text { rehabilitacijskog } \\
\text { tretmana }\end{array}$} & \multirow[t]{2}{*}{$\mathrm{T}$} & \multirow[t]{2}{*}{$p$} \\
\hline & M & SD & M & SD & & \\
\hline Osobna higijena & 2,21 & 0,89 & 4,71 & 1,23 & 4,263 & $<0,05$ \\
\hline Kupanje & 1,97 & 0,45 & 2,56 & 0,98 & 1,558 & 0,121 \\
\hline Hranjenje & 3,68 & 1,09 & 6,89 & 2,12 & 6,181 & $<0,05$ \\
\hline Korišstenje WC-a & 3,05 & 1,32 & 6,26 & 2,31 & 5,764 & $<0,05$ \\
\hline Penjanje uz stepenice & 1,67 & 0,67 & 2,22 & 0,76 & 0,634 & 0,457 \\
\hline oblačenje & 2,34 & 0,13 & 5,55 & 1,65 & 5,978 & $<0,05$ \\
\hline Kontrola stolice & 3,23 & 1,23 & 5,44 & 1,72 & 4,567 & $<0,05$ \\
\hline Kontrola mokrenja & 4,87 & 1,34 & 8,08 & 1,98 & 6,036 & $<0,05$ \\
\hline Transfer krevet/stolica & 4,78 & 1,48 & 7,99 & 1,32 & 8,976 & $<0,05$ \\
\hline Pokretljivost & 4,56 & 1,13 & 7,77 & 2,04 & 8,192 & $<0,05$ \\
\hline Korištenje kolica & 2,53 & 0,96 & 3,04 & 1,12 & 1,005 & 0,234 \\
\hline
\end{tabular}

Izmjereni su i rezultati razmjera utjecaja $\mathrm{MU} \mathrm{u}$ odnosu na stupanj depresije i anksioznosti. Pokazala se statistički značajna razlika u rezultatima u učestalosti depresije u ispitanika na početku i na kraju rehabilitacijskog programa $(\mathrm{p}=0,003)$ (Tablica 2$)$.

Tablica 2. Učestalost depresije u ispitanika izmjerena HADS upitnikom

\begin{tabular}{|c|c|c|c|c|c|c|}
\hline \multirow[t]{2}{*}{ Zbroj bodova - značenje } & \multicolumn{2}{|c|}{$\begin{array}{l}\text { Na početku } \\
\text { rehabilitacijskog } \\
\text { tretmana } \\
\end{array}$} & \multicolumn{2}{|c|}{$\begin{array}{l}\text { Na kraju } \\
\text { rehabilitacijskog } \\
\text { tretmana } \\
\end{array}$} & \multirow[t]{2}{*}{$\chi^{2}$} & \multirow[t]{2}{*}{$p$} \\
\hline & $\mathrm{Br}$. & $\%$ & $\mathrm{Br}$. & $\%$ & & \\
\hline <8 - nema naznaka depresije & 11 & 22,0 & 18 & 36,0 & \multirow{3}{*}{11,408} & \multirow{3}{*}{0,003} \\
\hline 8-10 - blaga depresija & 14 & 28,0 & 23 & 46,0 & & \\
\hline 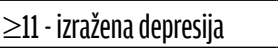 & 25 & 50,0 & 9 & 18,0 & & \\
\hline
\end{tabular}

Analizom učestalosti anksioznosti u ispitanika na početku i na kraju rehabilitacijskog tretmana nije se pokazala statistički značajna razlika (Tablica 3 ).

Tablica 3. Učestalost anksioznosti $u$ ispitanika izmjerena HADS upitnikom

\begin{tabular}{|c|c|c|c|c|c|c|}
\hline \multirow[t]{2}{*}{ Zbroj bodova - značenje } & \multicolumn{2}{|c|}{$\begin{array}{l}\text { Na početku } \\
\text { rehabilitaciijskog } \\
\text { tretmana }\end{array}$} & \multicolumn{2}{|c|}{$\begin{array}{l}\text { Na kraju } \\
\text { rehabilitaciijskog } \\
\text { tretmana }\end{array}$} & \multirow[t]{2}{*}{$\chi^{2}$} & \multirow[t]{2}{*}{$p$} \\
\hline & $\mathrm{Br}$. & $\%$ & $\mathrm{Br}$. & $\%$ & & \\
\hline <8 - nema naznaka anksioznosti & 19 & 38,0 & 25 & 50,0 & & \\
\hline 8-10 - blaga anksioznost & 18 & 36,0 & 16 & 32,0 & 1,663 & 0,435 \\
\hline$\geq 11$ - izražena anksioznost & 13 & 26,0 & 9 & 18,0 & & \\
\hline
\end{tabular}

U tablici 4 prikazani su Spearmanovi koeficijenti korelacije rangova između funkcionalnog oporavka u odnosu na razinu depresije i anksioznosti. Pokazala se statistički značajna negativna korelacija između funkcionalnog oporavka i razine depresije $(\mathrm{p}<0,05)$. Funkcionalni oporavak i razina anksioznosti nisu pokazale statistički značajnu povezanost.

Tablica 4. Povezanost funkcionalnog oporavka ispitanika s razinom depresije i anksioznosti utvrdena Spearmanovim koeficijentom korelacije

\begin{tabular}{lcc}
\hline \multirow{2}{*}{ Varijabla } & \multicolumn{2}{c}{ Funkcionalni oporavak } \\
\cline { 2 - 3 } & Spearman's rho & $p$ \\
\hline Rezultat za depresiju ostvaren u upitniku HADS & 0,923 & $<0,05$ \\
\hline Rezultat za anksioznost ostvaren u upitniku HADS & 0,083 & 0,270 \\
\hline
\end{tabular}

Obrađen je i Spearmanov koeficijent korelacije između funkcionalnog oporavka, razine depresije i anksioznosti u odnosu na životnu dob ispitanika. Pokazala se statistički značajna negativna korelacija između funkcionalnog oporavka i životne dobi $(\mathrm{p}<0,05)$ te pozitivna korelacija između razine depresije i životne dobi $(\mathrm{p}<0,05)$. To znači da je manji funkcionalni oporavak pacijenata značajno povezan $s$ njihovom većom životnom dobi, dok je veća razina depresije značajno povezana s većom životnom dobi ispitanika. Razina anksioznosti i životna dob nisu pokazale statistički značajnu povezanost (Tablica 5). 
Tablica 5. Povezanost funkcionalnog oporavka, razine depresije i anksioznosti ispitanika sa životnom dobi ispitanika utvrdena Spearmanovim koeficijentom korelacije

\begin{tabular}{lcc}
\hline \multirow{2}{*}{ Varijabla } & \multicolumn{2}{c}{ Životna dob } \\
\cline { 2 - 3 } & Spearman's rho & $p$ \\
\hline Rezultat ostvaren u Barthelov-om indeksu & 0,780 & $<0,05$ \\
\hline Rezultat za depresiju ostvaren u upitniku HADS & 0,872 & $<0,05$ \\
\hline Rezultat za anksioznost ostvaren u upitniku HADS & 0,118 & 0,116 \\
\hline
\end{tabular}

\section{RASPRAVA}

$\mathrm{U}$ ovom istraživanju analizirali smo učinak ranog kineziterapijskog programa na bolesnike s preboljenim moždanim udarom. Prema prikazanim rezultatima u ovom radu, muškarci su bili statistički značajno zastupljeniji u odnosu na žene. Lavados i suradnici u svojoj velikoj epidemiološkoj studiji navode da je među bolesnicima s MU 59 \% muškaraca i 41 \% žena (11). Slične rezultate u Španiji navode De Oliveira i suradnici u svojoj studiji u kojoj je među pacijentima s CVI $60 \%$ muškaraca i $40 \%$ žena (12). Mayo u svom istraživanju navodi da je stopa incidencije za CVI za 19 \% viša kod muškaraca nego kod žena (11). Od CVI obolijevaju u prvom redu starije osobe, mada se $28 \%$ od ukupnog broja CVI javlja kod mlađih od 65 godina (13). Starost je značajan faktor rizika za nastanak CVI, a stopa incidencije za CVI udvostručuje se za svaku deceniju poslije 55. godine (14). U ovoj studiji prosječna starost bolesnika iznosila 72,7 godina, a gotovo polovica pacijenata imala je preko 70 godina životne dobi. U studiji u Čileu, prosječna starost bolesnika s CVI, prema Lavadosu i suradnicima, iznosila je 68,4 godine (11). Prema podacima koje navodi De Oliviera i suradnici, u Brazilu je prosječna starost bolesnika iznosila 47,9 godina (12).

Parametar mjerenja učinkovitosti kineziterapijskog tretmana bio je Berthelov indeks. Određivanje Bartelovog indeksa na početku rane rehabilitacije pokazalo se iznimno korisnim, jer je inicijalna vrijednost BI dobar pokazatelj funkcionalnog oporavka pacijenta Kwakkel i suradnici preporučuju da BI najranije treba određivati petog dana od moždanog udara (15). Nakao i suradnici smatraju da vrijednost BI tri tjedna poslije doživljenog moždanog udara može pouzdanije ukazati na stupanj funkcionalnog oporavka koji se može očekivati šest mjeseci nakon moždanog udara (16).

Nakon provedenog kineziterapijskog tretmana došlo je do značajnog poboljšanja BI skora u ispitanika. Pokazalo se značajno kvalitetnije obavljanje svakodnevnih aktivnosti života u pacijenata pri otpustu s liječenja u odnosu na obavljanje navedenih aktivnosti tijekom prijema na odjel. Također uočeni stupanj ovisnosti pacijenata na prijemu se nakon provedenog ranog rehabilitacijskog programa pokazao statistički značajno smanjen. Mnoge studije pokazuju rana fizikalna terapija uveliko poboljšava funkcionalni oporavak i smanjuje broj bolesnika ovisnih o tuđoj pomoći $(17,18)$.

$\mathrm{U}$ našem istraživanju, među ispitanicima nakon MU, polovica je bila depresivna, dok ih je skoro trećina imala graničnu depresiju. Depresija je značajno utjecala na oporavak nakon moždanog udara. Lošije rezultate oporavka su imali bolesnici s klinički izraženom depresijom. Depresija nakon MU je udružena s lošijim funkcionalnim i psihosocijalnim ishodom te utječe na spoznajne sposobnosti, funkcionalni oporavak, kvalitetu življenja i zdravstvenu njegu bolesnika s preboljelim MU. Podaci iz literature govore da se prevalencija depresije nakon $\mathrm{MU}$ kreće od 20 do 65 \% (19). U istraživanju Wilkinsona, od 96 ispitanika koju su popunjavali HADS upitnik, njih $23 \%$ bilo depresivno, a $14 \%$ je pripadalo skupini granično depresivnih. Osamnaest ispitanika (19\%) u njegovu uzorku je imalo zbroj koji je ukazivao na kliničku anksioznost, a 12 (13\%) ih je bilo granično anksiozno, dok ih je 11 imalo elemente i anksioznosti i depresije (20). Ebrahim je sa svojim suradnicima ispitao 149 bolesnika 6 mjeseci nakon preboljelog ishemičnog inzulta. Svih $23 \%$ bolesnika kod kojih je dijagnosticirana depresija imalo je usporen funkcionalni fiziološki i kognitivni oporavak (21). Depresivnost nije bila podjednako izražena kod svih bolesnika koji su preboljeli inzult, već je češća kod onih starijih osoba koje imaju više rizičnih faktora primjerice kod onih koji su imali 
značajan negativni životni događaj 6 mjeseci prije incidenta (21). Oporavak dnevnih aktivnosti dobro utječe na oporavak depresije. Ispitujući 49 bolesnika poslije inzulta u 14 mjesečnom razdoblju Morris i suradnici su našli $41 \%$ bolesnika sa evidentnom depresijom. Ustanovljen je znatno sporiji oporavak motoričkih i kognitivnih sposobnosti kod skupine depresivnih (22).

U stručnoj literaturi može naći mnogo preporuka o neophodnosti ranog početka kineziterapijskog programa odmah po stabilizaciji zdravstvenog stanja u pacijenata koji imaju hemiparezu kao posljedicu MU. Richards i suradnici u svojoj opsežnoj meta-analizi navode učinkovitost ranog započinjanja ranog kineziterapijskog tretmana u liječenju hemiparetičnih posljedica u bolesnika nakon preboljelog MU (23). Sim i Wright u svojoj studiji naglašavaju potrebu kontinuiranosti ranog kineziterapijskog tretmana pacijenata $s$ hemiparezom $u$ stacionarnoj medicinskoj ustanovi i potrebu njegovog daljnjeg produljenja u indiciranim slučajevima (24). Autori navode da aktivnu rehabilitaciju treba nastaviti toliko dugo koliko to zahtijeva stanje bolesnika kao dio dugoročnog rehabilitacijskog programa. Rehabilitaciju treba početi što je ranije moguće, čak i kod komatoznih pacijenata, kojima je vrlo korisno mijenjanje položaja tijela, pravilno pozicioniranje $\mathrm{i}$ održavanje opsega pokreta. Takvi programi uključuju serije od 15 do 20 fizioterapeutskih tretmana, dva puta na godinu. Na taj se način održava status bolesnika postignut tijekom aktivnoga rehabilitacijskog programa. Rehabilitacijski programi ne mijenjaju neurološki deficit bolesnika, ali mogu puno pridonijeti njegovu osamostaljivanju. Najvažnija je činjenica da većina bolesnika nakon uspješno provedenoga rehabilitacijskog programa koji uključuje i na vrijeme započet kineziterapijski tretman može u svom domu samostalno obavljati aktivnosti, bez potrebe za stalnom sestrinskom njegom, što je veoma važan čimbenik i na ekonomskom i još važnije - na humanom planu.

Rezultati ovog istraživanja ujedno su pokazali i povezanost oporavka s psihološkim stanjem bolesnika s preboljelim MU. Složenost pratećih psiholoških pojava govori o potrebi detaljnijeg razumijevanju psiholoških aspekata u tretmanu oboljelih od MU. Osim kvalitetnog fizikalnog tretmana u liječenju ovih bolesnika od posebnog bi bilo uključivanje suportivnih terapijskih programa podrške za održavanje i poboljšanje kvalitete života tijekom njihovog liječenja i medicinske rehabilitacije.

\section{ZAKLJUČCI}

1. MU je treći uzrok smrtnosti muškaraca i žena u svijetu, poslije malignih bolesti i ishemijskih bolesti srca.

2. Muškarci značajno češće obolijevaju od moždanog udara u odnosu na žene.

3. Od MU prvenstveno obolijevaju osobe u životnoj dobi od 70 i više godina.

4. U istraživanju bolesnici su statistički značajno većom ocjenom ocijenili mogućnost obavljanja osobne higijene, hranjenja, korištenja WCa, oblačenja, pokretljivosti, kontrole mokrenja, transfera krevet/stolica i kontrole stolice na koncu svog rehabilitacijskog tretmana.

5. Nakon provedbe rehabilitacijskog tretmana učestalost depresije u ispitanika se pokazala značajno manja.

6. Primjena ranog kineziterapijskog tretmana dovodi do statistički značajnog funkcionalnog i psihološkog oporavka bolesnika sa preboljelim MU.

\section{LITERATURA}

1. Bakran Ž, Dubroja I, Habus S. Rehabilitacija osoba $s$ moždanim udarom. Medicina fluminensis. 2012; 48:380-94.

2. Dimitrijević J, Gavranović M, Strukar M, i sur. Klinički algoritam u diferencijalnoj dijagnozi rane faze moždanog udara. Med Žur. 1997; 3:142-8.

3. Gordon NF, Gulanick M, Costa F. Physical activity and exercise recommendations for stroke survivors. Circulation. 2004; 109:2031-41.

4. Schnurrer-Luke-Vrbanić T, Avancini-Dobrović V, Bakran Ž, Kadojić M. Smjernice za rehabilitaciju osoba nakon moždanog udara. Fiz. rehabil. med. 2015; 27:237-69. 
5. Stein J, Brandstater ME. Stroke rehabilitation. U: Frontera WR, urednik. DeLisa' Physical Medicine \& Rehabilitation. Philadelphia: Lippincott Williams \& Wilkins. 2010;551-74.

6. Goljar N. Klinične smernice za rehabilitacijo bolnikov po preboleli moždanski kapi (Clinical guidelines for rehabilitation of patients with stroke). 25.dnevni rehabilitacijske medicine, Ljubljana. 2014:12-4.

7. Gunes Y, Ruud S, Nebahat S. Mirror therapy improves hand function in subacute stroke: A randomized controlled trial. Arch Phys Med Rehabil. 2008;89:393-8.

8. American Heart Association - Prevention Conference IV: Prevention and rehabilitation of stroke. Circulation. 1997; 96:701-7.

9. Mahoney FL, Banhel DW. Functional evaluation: the Barthell index. Maryland State Med J. 1965;14:61.

10.Zigmond AS, Snaith RP. The Hospital Anxiety And Depression Scale. Acta Psychiatr Scand. 1983; 67:361-70.

11. Lavados MP, Sacks C, Prina L, Escobar A, Tossi C, Araya F, i sur. Incidence, case-fatality rate, and prognosis of ischameic stroke subtipes in a predominantly Hispanic-Mestizo population in Iquiqe, Chile: a community-based incidence study. Lancet Neurol. 2007; 6:140-8.

12. De Oliveira R, Cacho WEA, Borges G. Post-stroke motor and functional evaluations: a clinical correlation using Fugl-Meyer assessment scale, Berg balance scale and Barthel index. Arq Neuro-Psiquiatr. 2006; 64:731-5.

13. Mayo NE. Long-term consequences of stroke: epidemilogy and recovery. State Art Rev. 1993; 7:1-26.

14. Kollen B, Kwakkel G, Lindeman E. Functional recovery after stroke: a review of current developments in stroke rehabilitation research. Rev Recent Clin Trials. 2006; 1:75-80.

15. Kwakkel G, Veerbeek MJ, Harmeling-van der Wel BC; van Wegen E, Kollen BJ. Diagnostic accuracy of the barthel index for measuring activities of daily living outcome after ischemic he- mispheric stroke. Does early poststroke timing of assessment matter? Stroke. 2011; 42:342-6.

16. Nakao S, Takata S, Uemura H, Kashihara M, Osawa T, Komatsu K, i sur. Relationsheep between Barthel Index scores during the acute phase of rehabilitation and subsequent in stroke patients. J Med Invest. 2010; 57:81-8.

17. Murray E. Brandstater. Stroke rehabilitation. In: Joel A. Delisa (ed.) Physical medicine and rehabilitation, principles and practice. Lippincott Williams and Wilkins. 2004;1661-2.

18. Chatterton HJ, Pomeroy VM, Gratton J. Positioning for stroke patients: a survey of physiotherapists' aims and practices. Disabil Rehabil. 2001; 23:413-21.

19. Lai SM, Duncan PW, Keighley J, Johnson D. Depressive symptoms and independence in BADL and IADL. J Rehabil Res Dev. 2002; 39:589-96.

20. Wilkinson PR, Wolfe CD, Warburton FG, Rudd AG, Howard RS, Ross-Russell RW, Beech RR. A long-term follow-up of stroke patients. Stroke. 1997; 28:507-12.

21.Ebrahim S, Barer D, Nouri F. Affective Illness After Stroke. British Journal of Psychiatry. 2006; 151:52-6.

22. Morris PL, Robinson RG, Andrzejewski P, Samuels J, Price TR. Association of Depression With 10-Year Poststroke Mortality. American Journal of Psychiatry. 2003; 150:124-9.

23. Richards CL, Malouin F, Wood-Dauphinee S, Williams JI, Bouchard J-P, Brunet D. Task-specific physical therapy for optimization of gait recovery in acute stroke patients. Arch Phys Med Rehabil. 1993; 74:612-20.

24.Sim J, Wright CC. The kappa statistic in reliability studies: use, interpretation, and sample size requirements. Phys Ther. 2005; 85:257-68. 


\title{
EFFICIENCY EVALUATION OF EARLY KINESITHERAPY TREATMENT IN PATIENTS WITH STROKE
}

\author{
Sara Andrić ${ }^{1}$, Ljerka Ostojić1,2 \\ ${ }^{1}$ Physical Medicine and Rehabilitation Clinic, University Clinical Hospital Mostar \\ ${ }^{2}$ Faculty of Health Studies, University of Mostar, Bosnia and Herzegovina
}

\begin{abstract}
INTRODUCTION: Stroke is an acute brain circulation disorder with transient or permanent brain dysfunction.

OBJECTIVE: Evaluate the efficiency of early kinesitherapy treatment in mitigation of functional and psychological consequences of stroke in early stages of rehabilitation.

SUBJECTS AND METHODS: The study was conducted at the Physical Medicine and Rehabilitation Clinic at the University Clinical Hospital Mostar from November 1, 2016 to January 26, 2017. The study included 50 patients with recurrent stroke involved in kinesitherapy treatment. The Barthel index was used to evaluate the functional status of the subjects. RESULTS: $72 \%$ of the subjects were men ( $\mathrm{p}=0,001)$. The average age of the subjects was $72.7 \pm 7.3$ years. $48 \%$ of the subjects $(\mathrm{p}<0.05)$ were at the age of 70 and over. The total average score achieved on the Barthel index at the beginning of the rehabilitation treatment was $38.49 \pm 10.69$, while at the end of the treatment it was $50.65 \pm 13.27(\mathrm{p}<0.001)$. There was a statistically significant lower incidence of depression in subjects at the end of the rehabilitation program $(p=0.003)$ as well as a statistically significant correlation between functional recovery versus depression $(\mathrm{p}<0.05)$ and life expectancy $(\mathrm{p}<0.05)$. CONCLUSION: Early kinesitherapy treatment leads to a statistically significant functional and psychological recovery of patients with recurrent stroke.
\end{abstract}

Key words: efficiency, kinesitherapy, stroke, rehabilitation.

Correspondence:

Sara Andrić, Master of physiotherapy; e-mail: saraandric666@gmail.com 